\title{
A Research Study on the Causes, Consequences and Remedies to Local Failures in Structural Elements in Buildings: A Case Study of Lagos State
}

\author{
Nwaigwe D.N, Ugonna M.C, Kenechukwu E. Nnebe, Olaifa O.A, \\ Nigerian Building and Road Research Institute \\ Federal Ministry of Science and Technology \\ Nigeria
}

\begin{abstract}
The frequency at which buildings fail in Nigeria has become a serious concern, embarrassment and challenge to the construction industry. This occurrence has affected the entire human endeavor ranging from psychosomatic upset where lives, property are lost in their numbers. This paper is targeted at using structured questionnaires meticulously administered to over 300 professionals and clients in the construction industry. This exercise is intended to ascertain the leading types of building failures, causes, consequences of building failures and remedies to building collapse. The five Likert scale comprising strongly agree, agree, undecided, disagree and strongly disagree were employed. The responses were afterward analyzed using statistical variables like the weighted average, mean, ranking indexes. Based on the analysis obtained, the leading types of building failure ranges from Functional failure, Carbonation of concrete, Corrosion of reinforcement, spalling of members, Staining and soiling of the finishes. The causes of failure from the analysis were found to be Errors of computation in design, failure to account for loads the structure is expected to carry, erroneous theories in design, bad management decisions, frauds, not building according to drawing and specifications by the contractor. The consequences of local failures are reduction of flexural rigidity of the elements, collapse of building, adverse effect on appearance and Injuries/death Remedies obtain were to anticipate the most extreme way the material can contribute to a failure when selecting materials, building envelopes must resist thermal transfer and block movement of air and water from one side to another, make provisions for wet materials to dry out within the mold, ensure woods are not too dry or too wet. It is however of great importance for all stakeholders involved to rise to the situation thereby bringing about necessary changes in the built industry.
\end{abstract}

Keywords: Local Failure, Structural Element, Building, Professionals.

\subsection{INTRODUCTION}

Building can be defined as a structure with a roof and walls such as a house or a factory [1]. The wall here may include columns, beams to support floor slab, down to foundation which transfer the load from superstructure to sub-structure or bedrock. Collapse for a layman can be defined as a suddenly fall down or give way, or sudden failure [1].As soon as collapse occurs, there is little or no repair to restore to normality or completely. Structural elements such as slabs, beams, columns and foundations are elements designed and created to safely and economically transmit load from point of application to point of support [2]. They are composed of steel and concrete adequately bounded together since steel is strong in tension; it provides much of tensile strength required by the member while concrete which is strong in compression and weak in tension assists the steel in carrying the required tensile stress [2]. These structural elements will fail partially or totally when unduly overloaded or not built to specifications. These local or partial failures could be caused by exposure of reinforcement (in slabs, beams and columns), buckling of columns, slab and beam deflections, uneven settlement of foundations etc [3]. These local failures reduce the flexural rigidity of the elements, have adverse effect on appearance and consequently, if not properly remedied, lead to total collapse of building. It is therefore, necessary to study the causes of these local failures and suggest remedies to them, because of the serious consequences; it may have on safety of structures, lives and properties.

Deficiency in basic design and detailing of a member to provide sufficient resistance to normal loading is one of the causes of local problem in building [3]. The characteristic strength of concrete used in the design of structural elements is often higher than that achieved by local contractors. Also the characteristic strength of reinforcement recommended in British code used in design is often higher than that produced locally. [4]. Since the strength of concrete achieved by local contractors does not measure up to that used in design, the resistance of the concrete is drastically reduced when this already reduced tensile resistance of the concrete 
has been exceeded, failure in bond between concrete and steel occurs and finally exposes the reinforcement. Spall and exposure of reinforcement also occur due to poor detailing of structural elements, insufficient lap length especially in beams and columns to transfer stresses from one bar to the other [5-6].

Failure is an unacceptable difference between expected and observed performance. A failure can be considered occurring in an element when that element can no longer be relied upon to fulfil its principal functions. Excessive deflection resulting in serious damage to partitions, ceilings and floor finishes could be classed as a failure [6-7], ascribed faulty design, and faulty execution of work and use of faulty materials as major cause of structural failures. [7-8] attributed building failures in Nigeria to the following causes design faults (50\%), faults on construction site (40\%) and product failure (10\%).

Idrus, A.B [9] categorized the following as major causes of structural failures. Environmental changes, natural and man-made hazards, improper presentation and interpretation in the design. Ejeh, S.P [10] opined that deterioration of reinforced concrete could occur as a result of corrosion of the reinforcement caused by carbonation and chloride ingress, cracking caused by overloading, subsidence or basic design faults and construction defects.

\subsubsection{AIM AND OBJECTIVES}

The aim of this study is to identify the various possible causes, consequences and remedies to local failures in buildings. The specific objectives are:

- To administer structured questionnaires to professionals in the built industry

- To seek relevant professional data within the built industry

- To determine weighted average, mean and ranking indexes

- To use the ranking technique to ascertain the leading causes, consequences and remedies to local failure in buildings

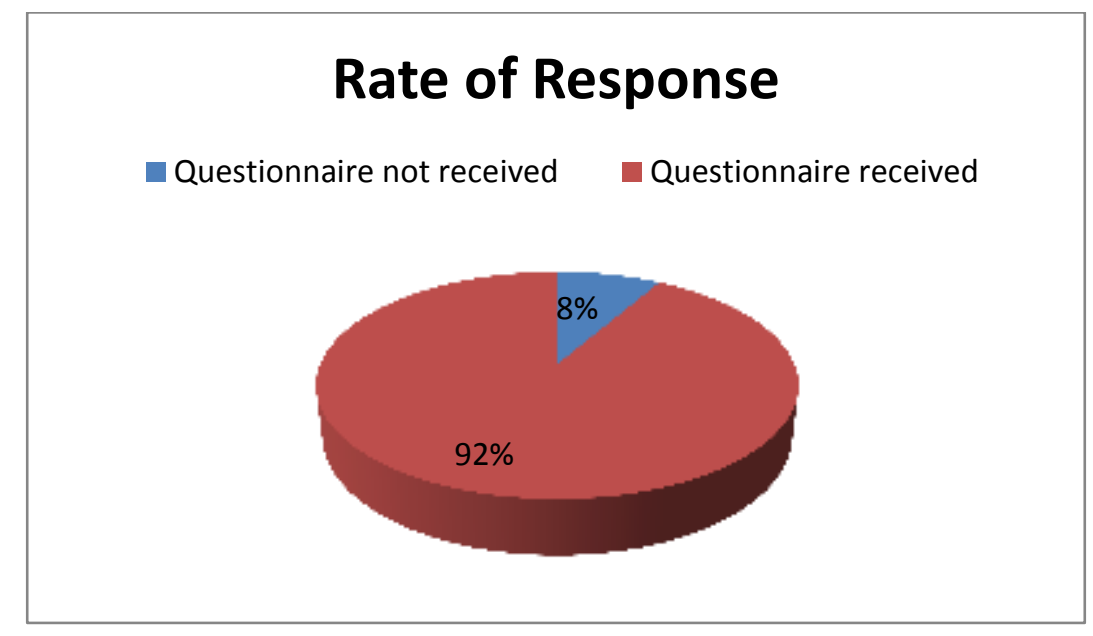

Figure 1.1: Rate of Response

\subsection{ANALYSIS ON RESPONSE}

Figure 1.1 shows that 600 questionnaires were administered and 550 were recovered. This represents a response rate of $92 \%$ while those that were not received are $8 \%$. It is an indication of good response from responders. 


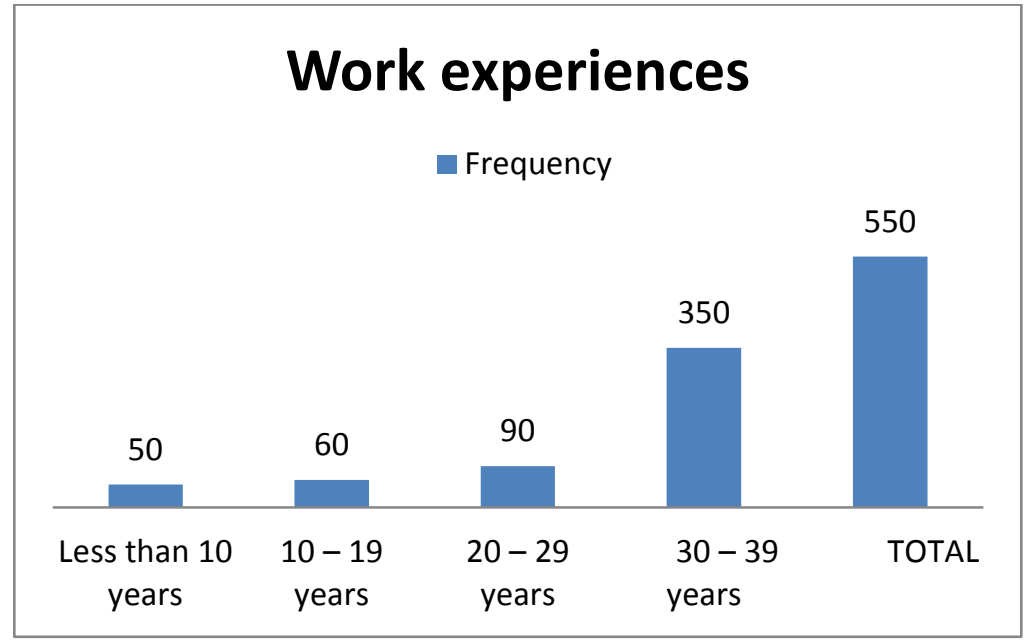

Figure 1.2: Work Experiences

\subsection{ANALYSIS ON WORK EXPERIENCES}

Figure 1.2 shows that 50 of the responders, most of who are professionals in the built environment have less than 10 years of work experience and 60 have 10 to 19 years of experience. Furthermore, 90 have 20- 29 years of work experience, while 350 have 3039 years of experience. This shows that $64 \%$ of the responders who are mainly professionals in the built environment have 30 to 39 years of experience; meaning that they possess adequate years of cognate experience.

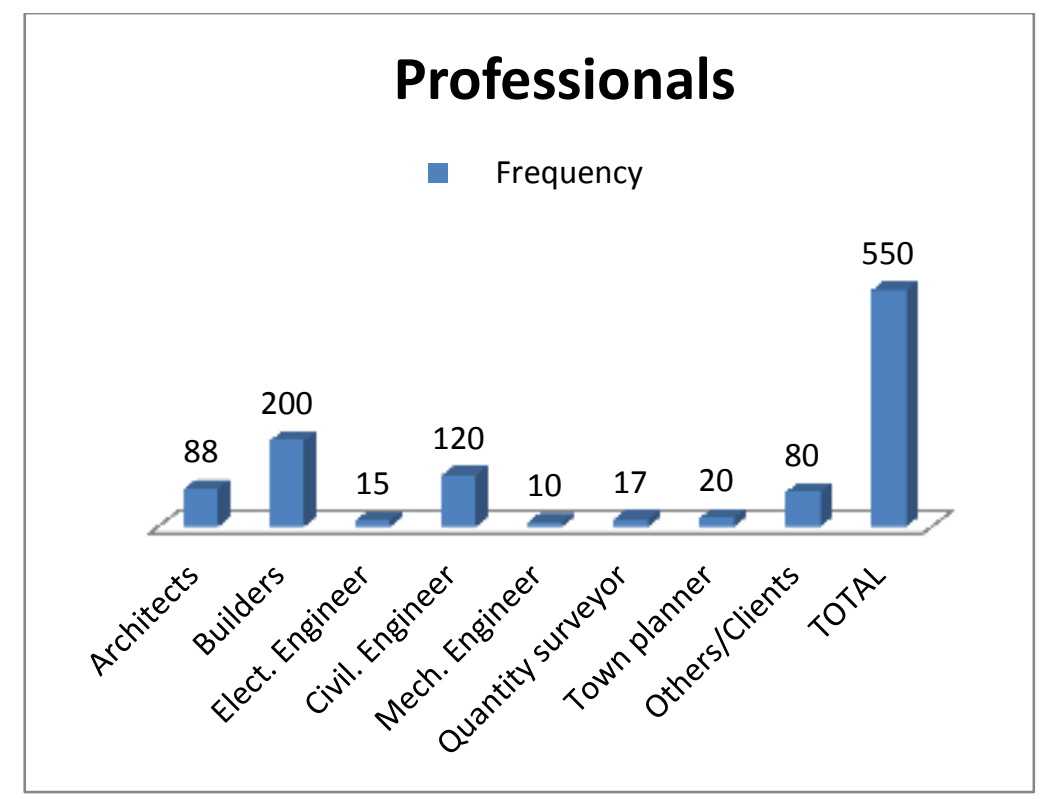

Figure 1.3: Professionals

\subsection{ANALYSIS ON PROFESSIONALS}

Figure 1.3 shows that $16 \%$ of the responders were Architects, $2.7 \%$ were Electrical engineers, $36.4 \%$ were builders, $1.8 \%$ was Mechanical engineers, $21.8 \%$ were Civil engineers, $3.1 \%$ were Quantity surveyors, $3.6 \%$ were town planners and $14.5 \%$ were other profession related and clients in the built environment. Thus, the responders are capable of providing information for this study based on professional point of view. 


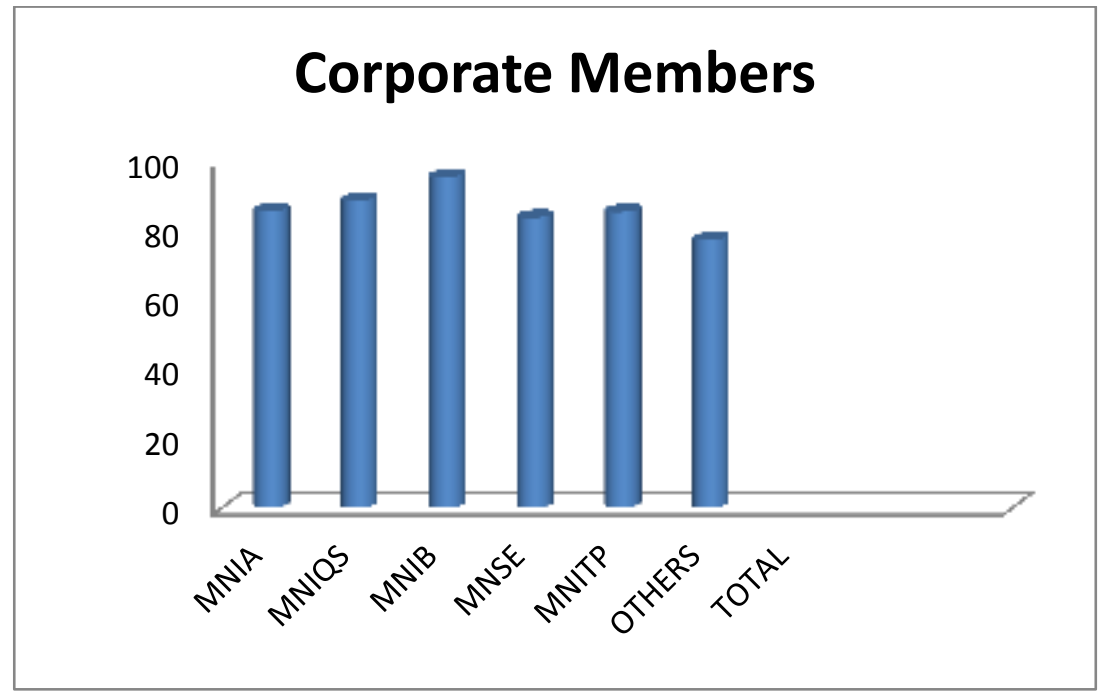

Figure 1.4: Corporate Members

\subsection{ANALYSIS ON CORPORATE MEMBERS}

Figure 1.4 shows that 75 out of 88 , of the responders were registered architects, 15 out of 17 were registered quantity surveyors, 190 out of 200 were registered builders, 100 out of 120 were registered engineers and 100 out of 130 were other professionals related to the built environment. This showed that the responders were primarily registered professionals and is expected to be better informed on local failures in structural elements of buildings.

\subsection{METHODOLOGY}

\subsection{PRIMARY DATA}

Primary data would have been gotten from the administration of structured questionnaires, visual inspections and in-situ testing of materials in the study areas. Questionnaires would be divided into 3 sections. Section A and B would be administered to all professionals in design construction team while section $\mathrm{A}$ and $\mathrm{C}$ would be administered to clients. The visual inspection would reveal the position, types and sizes of structural elements used, nature and size of reinforcement, the cover to reinforcement, the geology of the areas, design calculations and drawings. The in-situ testing would involve non-destructive test and destructive test. The non-destructive test would make use of the concrete test hammer and the ultrasonic pulse velocity machine. This would give approximate information on the strength of the structural elements. The non-destructive test would also involve the use of the cover metre to determine the location and cover to reinforcement embedded in the concrete. On the other hand, the destructive test would make use of X-ray coring machine and penetration resistance apparatus. This would provide compressive strength and possible tensile strength of materials.

\subsection{SECONDARY DATA}

The secondary data would be gotten from Nigerian Institute of Building (NIOB), Nigerian Institute of Structural Engineers (NISE), Council for the Regulation of Engineering (COREN), local authority (Town planners), Ministry of Environment and few media houses. The information to be gotten from the aforesaid bodies/establishments is expected to reveal some possible causes of structural failures and building collapses and also the effects on lives and properties.

\subsection{METHOD OF DATA ANALYSIS}

In this study, the respondents were requested to rate their level of agreement with the identified attributes on a 5-point Likert scale ( $1=$ strongly disagree, $2=$ disagree, $3=$ neutral, $4=$ agree and $5=$ strongly agree). The designated value of $1,2,3,4$ and 5 were u sed to allot weight to the options in the course of analysis. The Weighted Value (WV) for each criterion was obtained by the product of the number of responses for each rating to a criterion and the respective weight of the value expressed as:

$$
W V=F_{i} * V_{i}
$$

Where $\mathrm{WV}$ is the weight value, $F_{i}$ is the frequency of respondents rating attributes i and $V_{i}$ is the weight attached to attribute i. 
The Summation of Weighted Value (SWV) for each factor was obtained by summing the product of the number of responses for each rating to a criterion and the respective weight of the value expressed as:

$$
S W V=\sum_{i=0}^{5} F_{i} * V_{i}
$$

Where SWV was the total weight value, $F_{i}$ is the frequency of respondents rating criterion i and $V_{i}$ was the weight attached to attribute $\mathrm{i}$. The average mean score was obtained by dividing the SWV of each and the total number of responders $(\mathrm{N}=550)$. This was expressed as:

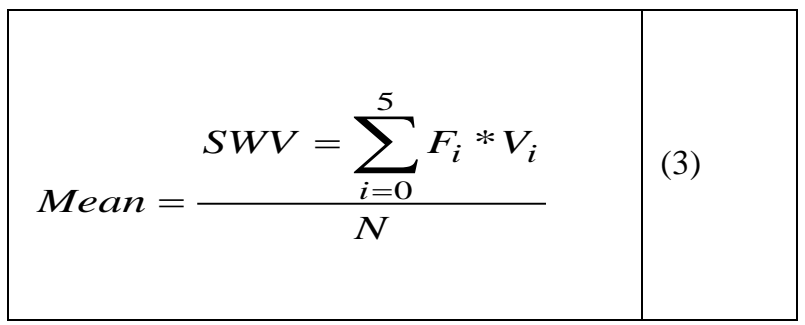

RII is a structured technique to quantify the relative variation. The analysis is similar to that of mean ranking. However, RII was obtained in this study by dividing the SWV of each attribute by the product of the highest rating score $(\mathrm{A}=5)$ and the total number of respondents $(\mathrm{N}=550)$. This was expressed as:

$$
R I I=\frac{S W V=\sum_{i=0}^{5} F_{i} * V_{i}}{N * A}
$$

\subsection{TYPES OF FAILURE}

The ranking indexes for the attributes were later computed from the results of the ratings generated from the analysis.

\begin{tabular}{|c|c|c|c|c|c|c|}
\hline \multirow{3}{*}{ Types of Failure } & \multicolumn{6}{|c|}{ Type of Storey buildings } \\
\hline & \multicolumn{2}{|c|}{$\begin{array}{l}\text { Above three } \\
\text { Storey }\end{array}$} & \multicolumn{2}{|c|}{ Three Storey } & \multicolumn{2}{|c|}{ Two Storey } \\
\hline & RII & Rank & RII & Rank & RII & Rank \\
\hline Aesthetic failure & 0.966 & 3 & 0.938 & 5 & 0.966 & 3 \\
\hline Concrete shrinkage cracking & 0.786 & 12 & 0.905 & 7 & 0.84 & 8 \\
\hline Flaking and peeling of paintwork & 0.793 & 11 & 0.705 & 17 & 0.751 & 14 \\
\hline Staining and soiling of the finishes & 0.959 & 4 & 0.962 & 2 & 0.982 & 1 \\
\hline Functional failure & 0.986 & 1 & 0.951 & 4 & 0.972 & 2 \\
\hline $\begin{array}{l}\text { Leaks in elements such as roofs, } \\
\text { walls and floors }\end{array}$ & 0.924 & 6 & 0.831 & 10 & 0.809 & 10 \\
\hline Failure of materials & 0.834 & 9 & 0.836 & 9 & 0.831 & 9 \\
\hline $\begin{array}{l}\text { Chemical attack of rendering or } \\
\text { concrete, mortar or brick }\end{array}$ & 0.979 & 2 & 0.964 & 1 & 0.982 & 1 \\
\hline Fungal attack of timber & 0.966 & 3 & 0.959 & 3 & 0.972 & 2 \\
\hline $\begin{array}{l}\text { System failure of components and } \\
\text { elements }\end{array}$ & 0.897 & 7 & 0.856 & 8 & 0.883 & 7 \\
\hline Carbonation of concrete & 0.986 & 1 & 0.951 & 4 & 0.963 & 4 \\
\hline $\begin{array}{l}\text { Corrosion of reinforcement and } \\
\text { spalling of members }\end{array}$ & 0.986 & 1 & 0.921 & 6 & 0.926 & 5 \\
\hline
\end{tabular}

Table 1.1: Types of failure on different storey buildings 
International Journal of Engineering Research And Advanced Technology, Vol.5, Issue 10, October-2019

\begin{tabular}{|l|c|c|c|c|c|c|}
\hline $\begin{array}{l}\text { Subsidence caused by downward } \\
\text { movement of building }\end{array}$ & 0.807 & 10 & 0.8 & 11 & 0.8 & 11 \\
\hline Deboning of plaster & 0.772 & 14 & 0.754 & 13 & 0.742 & 15 \\
\hline Roof tiles and slate are delamination & 0.779 & 13 & 0.728 & 15 & 0.769 & 13 \\
\hline $\begin{array}{l}\text { Excessive distortion in beam, column } \\
\text { or wall owing to structural movement }\end{array}$ & 0.938 & 5 & 0.905 & 7 & 0.902 & 6 \\
\hline $\begin{array}{l}\text { Quality and availability of regulator } \\
\text { documentation }\end{array}$ & 0.869 & 8 & 0.795 & 12 & 0.809 & 10 \\
\hline Site condition & 0.71 & 16 & 0.751 & 14 & 0.775 & 12 \\
\hline Air quality impact & 0.566 & 18 & 0.618 & 20 & 0.643 & 19 \\
\hline Noise level impact & 0.628 & 17 & 0.621 & 19 & 0.671 & 18 \\
\hline Waste management around the site & 0.71 & 16 & 0.672 & 18 & 0.708 & 17 \\
\hline Climate condition & 0.745 & 15 & 0.708 & 16 & 0.729 & 16 \\
\hline
\end{tabular}

\subsection{ANALYSIS ON TYPES OF FAILURE}

Table 1.1 shows various types of failure peculiar to the built industry. From the analysis obtained, the leading failures as shown from the table for different storey buildings are: Functional failure, Carbonation of concrete, Corrosion of reinforcement, spalling of members, Staining and soiling of the finishes.

Table 1.2: Causes of local failure in buildings

\begin{tabular}{|c|c|c|c|c|c|c|c|c|}
\hline Causes of Failure & 1 & 2 & 3 & 4 & 5 & SWV & RII & Rank \\
\hline $\begin{array}{l}\text { Not building according to drawing } \\
\text { and specifications by contractor }\end{array}$ & 0 & 2 & 15 & 176 & 610 & 803 & 0.934 & $5^{\text {th }}$ \\
\hline $\begin{array}{l}\text { Inadequate supervision and control of } \\
\text { site operation and quality control }\end{array}$ & 1 & 4 & 66 & 468 & 150 & 689 & 0.801 & $14^{\text {th }}$ \\
\hline Extra-ordinary load & 1 & 2 & 135 & 464 & 45 & 647 & 0.752 & $16^{\text {th }}$ \\
\hline Earthquake/hurricane/heavy rain & 1 & 12 & 177 & 292 & 165 & 647 & 0.752 & $16^{\text {th }}$ \\
\hline $\begin{array}{l}\text { Defective site (sinking holes or } \\
\text { swampy land) }\end{array}$ & 0 & 2 & 39 & 196 & 545 & 782 & 0.909 & $8^{\text {th }}$ \\
\hline Errors of computation in design & 0 & 2 & 9 & 72 & 750 & 833 & 0.969 & $1^{\text {st }}$ \\
\hline $\begin{array}{l}\text { Failure to account for loads the } \\
\text { structure is expected to carry }\end{array}$ & 0 & 2 & 12 & 160 & 635 & 809 & 0.941 & $3^{\text {rd }}$ \\
\hline Erroneous theories in design & 0 & 4 & 18 & 124 & 665 & 811 & 0.943 & $2^{\text {nd }}$ \\
\hline Reliance on inaccurate data & 0 & 2 & 27 & 352 & 370 & 751 & 0.873 & $9^{\text {th }}$ \\
\hline $\begin{array}{l}\text { Improper choice of materials/ } \\
\text { misunderstanding their properties }\end{array}$ & 0 & 2 & 150 & 268 & 270 & 690 & 0.802 & $13^{\text {th }}$ \\
\hline Lack of experience & 0 & 6 & 174 & 368 & 95 & 643 & 0.748 & $16^{\text {th }}$ \\
\hline Poor labor productivity & 1 & 0 & 54 & 448 & 205 & 708 & 0.823 & $10^{\text {th }}$ \\
\hline Bad management decisions & 1 & 6 & 30 & 92 & 675 & 804 & 0.935 & $4^{\text {th }}$ \\
\hline Frauds & 0 & 2 & 39 & 128 & 630 & 799 & 0.929 & $6^{\text {th }}$ \\
\hline Lack of control/supervision system & 0 & 14 & 255 & 244 & 95 & 608 & 0.707 & $17^{\text {th }}$ \\
\hline Lack of communication system & 0 & 20 & 243 & 248 & 95 & 606 & 0.705 & $19^{\text {th }}$ \\
\hline $\begin{array}{l}\text { Lack of experience by building } \\
\text { contractor }\end{array}$ & 0 & 12 & 48 & 416 & 230 & 706 & 0.821 & $11^{\text {th }}$ \\
\hline Faulty execution of work & 0 & 2 & 27 & 216 & 540 & 785 & 0.913 & $7^{\text {th }}$ \\
\hline $\begin{array}{l}\text { Buckling of columns, slab and beam } \\
\text { deflections }\end{array}$ & 0 & 6 & 36 & 512 & 145 & 699 & 0.813 & $12^{\text {th }}$ \\
\hline Uneven settlement of foundations & 0 & 14 & 129 & 420 & 85 & 648 & 0.753 & $15^{\text {th }}$ \\
\hline Use of faulty materials & 7 & 52 & 267 & 176 & 30 & 532 & 0.619 & $20^{\text {th }}$ \\
\hline
\end{tabular}




\subsection{ANALYSIS ON CAUSES OF FAILURE}

Table 1.2 shows various causes of failure common to the built industry. From the analysis obtained, the leading causes of failures as shown are: Errors of computation in design, failure to account for loads the structure is expected to carry, erroneous theories in design, bad management decisions, frauds, not building according to drawing and specifications by contractor.

Table 1.3: Consequences of local failure in buildings

\begin{tabular}{|c|c|c|c|c|c|c|c|c|}
\hline Consequences of Failure & 1 & 2 & 3 & 4 & 5 & SWV & RII & Rank \\
\hline Injuries/death & 0 & 2 & 15 & 176 & 610 & 803 & 0.934 & $4^{\text {th }}$ \\
\hline Structural damage & 1 & 4 & 66 & 468 & 150 & 689 & 0.801 & $8^{\text {th }}$ \\
\hline Damage to contents & 1 & 2 & 135 & 464 & 45 & 647 & 0.752 & $9^{\text {th }}$ \\
\hline Loss of functionality & 1 & 12 & 177 & 292 & 165 & 647 & 0.752 & $9^{\text {th }}$ \\
\hline Environmental damage & 0 & 2 & 39 & 196 & 545 & 782 & 0.909 & $5^{\text {th }}$ \\
\hline $\begin{array}{l}\text { local failures reduce the flexural } \\
\text { rigidity of the elements }\end{array}$ & 0 & 2 & 9 & 72 & 750 & 833 & 0.969 & $1^{\text {st }}$ \\
\hline have adverse effect on appearance & 0 & 2 & 12 & 160 & 635 & 809 & 0.941 & $3^{\text {rd }}$ \\
\hline collapse of building & 0 & 4 & 18 & 124 & 665 & 811 & 0.943 & $2^{\text {nd }}$ \\
\hline $\begin{array}{l}\text { poor detailing of structural } \\
\text { elements, insufficient lap length } \\
\text { especially in beams and columns }\end{array}$ & 0 & 2 & 27 & 352 & 370 & 751 & 0.873 & $6^{\text {th }}$ \\
\hline $\begin{array}{l}\text { Excessive deflection resulting in } \\
\text { serious damage to partitions, } \\
\text { ceilings and floor finishes }\end{array}$ & 0 & 2 & 150 & 268 & 270 & 690 & 0.802 & $7^{\text {th }}$ \\
\hline
\end{tabular}

\subsection{ANALYSIS ON CONSEQUENCES OF LOCAL FAILURE}

Table 1.3 shows various consequences of failure common to the built industry. From the analysis obtained, the leading consequences of failures as shown are: local failures reduce the flexural rigidity of the elements, collapse of building, adverse effect on appearance and Injuries/death

Table 1.4: Remedies to local failure in buildings

\begin{tabular}{|l|r|r|r|r|r|r|r|r|}
\hline Remedies to Failure & $\mathbf{1}$ & $\mathbf{2}$ & $\mathbf{3}$ & $\mathbf{4}$ & $\mathbf{5}$ & SWV & RII & Rank \\
\hline $\begin{array}{l}\text { Anticipate the most extreme } \\
\text { way the material can contribute } \\
\text { to a failure when selecting } \\
\text { materials }\end{array}$ & 0 & 2 & 15 & 176 & 610 & 803 & 0.934 & $1^{\text {st }}$ \\
\hline $\begin{array}{l}\text { Make provisions for wet } \\
\text { materials to dry out within the } \\
\text { mold }\end{array}$ & 1 & 4 & 66 & 468 & 150 & 689 & 0.801 & $3^{\text {rd }}$ \\
\hline $\begin{array}{l}\text { Ensure woods are not too dry or } \\
\text { too wet }\end{array}$ & 1 & 2 & 135 & 464 & 45 & 647 & 0.752 & $4^{\text {th }}$ \\
\end{tabular}


International Journal of Engineering Research And Advanced Technology, Vol.5, Issue 10, October-2019

\begin{tabular}{|c|c|c|c|c|c|c|c|c|}
\hline $\begin{array}{l}\text { Prioritize the continuity of } \\
\text { building envelopes }\end{array}$ & 1 & 12 & 177 & 292 & 165 & 647 & 0.752 & $4^{\text {th }}$ \\
\hline $\begin{array}{l}\text { Building envelopes must resist } \\
\text { thermal transfer and block } \\
\text { movement of air and water from } \\
\text { one side to another }\end{array}$ & 0 & 2 & 39 & 196 & 545 & 782 & 0.909 & $2^{\text {nd }}$ \\
\hline $\begin{array}{l}\text { Building assemblies must be } \\
\text { designed to accommodate } \\
\text { seismic forces }\end{array}$ & 0 & 2 & 9 & 72 & 750 & 833 & 0.969 & $1^{\text {st }}$ \\
\hline Good \& Adequate Supervision & 0 & 2 & 12 & 160 & 635 & 809 & 0.941 & $3^{\text {rd }}$ \\
\hline Use Of Standard Materials & 0 & 4 & 18 & 124 & 665 & 811 & 0.943 & $2^{\text {nd }}$ \\
\hline $\begin{array}{l}\text { Involvement Of Professional } \\
\text { Builders In The Construction } \\
\text { Process }\end{array}$ & 0 & 2 & 27 & 352 & 370 & 751 & 0.873 & $10^{\text {th }}$ \\
\hline Soil Investigation & 0 & 2 & 150 & 268 & 270 & 690 & 0.802 & $14^{\text {th }}$ \\
\hline $\begin{array}{l}\text { Discipline Of Professionals, If } \\
\text { Proven They Are Involved In } \\
\text { Failures }\end{array}$ & 0 & 6 & 174 & 368 & 95 & 643 & 0.748 & $17^{\text {th }}$ \\
\hline $\begin{array}{l}\text { Promulgation Of Appropriate } \\
\text { Legislation Against Building } \\
\text { Failure }\end{array}$ & 1 & 0 & 54 & 448 & 205 & 708 & 0.823 & $11^{\text {th }}$ \\
\hline $\begin{array}{l}\text { Compliance To Approved } \\
\text { Drawings }\end{array}$ & 1 & 6 & 30 & 92 & 675 & 804 & 0.935 & $4^{\text {th }}$ \\
\hline $\begin{array}{l}\text { Proper Check Of Detailing By } \\
\text { Builder And Design }\end{array}$ & 0 & 2 & 39 & 128 & 630 & 799 & 0.929 & $6^{\text {th }}$ \\
\hline $\begin{array}{l}\text { Correct Use And Installation Of } \\
\text { Fittings }\end{array}$ & 0 & 14 & 255 & 244 & 95 & 608 & 0.707 & $19^{\text {th }}$ \\
\hline $\begin{array}{l}\text { Involvement Of Professional } \\
\text { Builders In The Composition Of } \\
\text { Building Regulation }\end{array}$ & 0 & 20 & 243 & 248 & 95 & 606 & 0.705 & $20^{\text {th }}$ \\
\hline $\begin{array}{l}\text { Strict Compliance To Data } \\
\text { Available And Geotechnical } \\
\text { Properties Of The Soil }\end{array}$ & 0 & 12 & 48 & 416 & 230 & 706 & 0.821 & $12^{\text {th }}$ \\
\hline $\begin{array}{l}\text { Prompt And Necessary Measure } \\
\text { Towards Deterioration \& Defect }\end{array}$ & 0 & 2 & 27 & 216 & 540 & 785 & 0.913 & $7^{\text {th }}$ \\
\hline $\begin{array}{l}\text { Publicity Of The Consequences } \\
\text { Of Illegal Buildings }\end{array}$ & 0 & 6 & 36 & 512 & 145 & 699 & 0.813 & $13^{\text {th }}$ \\
\hline Enforcement Of Insurance Of & 0 & 14 & 129 & 420 & 85 & 648 & 0.753 & $16^{\text {th }}$ \\
\hline
\end{tabular}




\begin{tabular}{|l|r|r|r|r|r|r|r|l|}
\hline Buildings Against Failures & & & & & & & & \\
\hline Adequate Site Investigation & 7 & 52 & 267 & 176 & 30 & 532 & 0.619 & $23^{\text {th }}$ \\
\hline $\begin{array}{l}\text { Education Of The Occupiers Of } \\
\text { The Building }\end{array}$ & 3 & 22 & 333 & 168 & 25 & 551 & 0.641 & $22^{\text {th }}$ \\
\hline Adequate Maintenance & 1 & 8 & 255 & 316 & 15 & 595 & 0.692 & $21^{\text {rd }}$ \\
\hline
\end{tabular}

\subsection{ANALYSIS ON REMEDIES OF LOCAL FAILURE}

Table 1.4 shows various remedies to local failure common to the built industry. From the analysis obtained, the leading remedies to failures as shown are: Anticipate the most extreme way the material can contribute to a failure when selecting materials, Building envelopes must resist thermal transfer and block movement of air and water from one side to another, Make provisions for wet materials to dry out within the mold, ensuring woods are not too dry or too wet

\subsection{CONCLUSION}

The entire study adopted the ranking technique to ascertain the leading causes, consequences and remedies to local failure in buildings in Nigeria. The five Likert scale comprising strongly agree, agree, undecided, disagree and strongly disagree were employed for all participants. The responses were afterward analyzed using statistical variables like the weighted average, mean, ranking indexes. Based on the analysis obtained, the leading types of building failure ranges from Functional failure, Carbonation of concrete, Corrosion of reinforcement, spalling of members, Staining and soiling of the finishes. The causes of failure from the analysis were found to be Errors of computation in design, failure to account for loads the structure is expected to carry, erroneous theories in design, bad management decisions, frauds, not building according to drawing and specifications by contractor. The consequences of local failures are reduction of flexural rigidity of the elements, collapse of building, adverse effect on appearance and Injuries/death Remedies obtain were to anticipate the most extreme way the material can contribute to a failure when selecting materials, building envelopes must resist thermal transfer and block movement of air and water from one side to another, make provisions for wet materials to dry out within the mold, ensure woods are not too dry or too wet.

\section{REFERENCES}

1. Ejeh, S.P. "Safety Aspects of Design of Concrete and Steel Structure: Tech-grade Consulting". A 3-day workshop on Why Building Collapse and Preventive Measures held at Merit House, Abuja on 14th-16th September, 2010.

2. Oribuyaku, J.T. "Legal Sanctions Against culprits of Collapsed Buildings under Nigerian Laws". Tec grade Consulting. A 3-day workshop on Why Building collapse and preventive measures held at Merit House, Abuja, on 14-16th September, 2010.

3. Kong, E.K. and Evans, R.H. Reinforced and Pre-stressed Concrete. Thomas Nelson and Sons Ltd., 36 Park Street, London, WIY 3DE, 2012, pp 1-13.

4. Astill, W and Martin, L.H. Elementary Structural Design in Concrete. Edward Arnold Ltd., 25 Hill Street, London, W1X 8LL, 2012, pp. 1-14.

5. Daramola, Adedeji and Ayo-Vaughan, Adekunle, "Disaster in Building: The National Building code and Capacity Building in Nigerian Architectural Practice”. School of Architecture, Covenant University, Ota, Nigeria, June, 2004, pp. 13-16.

6. Fagbenle, Olubosipo, I. and Oluwunmi, Adedamola, O., "Building Failure and Collapse in Nigeria: The Influence of the Informal Sector". Journal of Sustainable Development, Vol. 3, No. 4 December, 2010. A Publication of Canadian Centre of Science and Education, pp. 269-277.

7. Orumu, S.F. "Failure Analysis of Collapse Buildings in Nigeria: A Case Study of Port Harcourt, River State. "Tec grade Consulting". A 3-day Workshop on "Why Building collapse and Preventive Measures" held at Merit House, Abuja on $14^{\text {th }}$ September, 2010, pp. 1-9.

8. Idrus, A.B. and Sondagi, J.B. Construction related factors influencing choice of concrete floor systems. Construction Management and Economics, 20, 13-19, 2010.

9. Imbert I.D. Human Issues Affecting Construction in Developing Countries, Construction Management and Economics, 8(2), 219-228, 1990.

10. Jaselskis, E. and Ashley, D. Optimal allocation of project management resources for achieving success. Journal of Construction Engineering and Management, 117, 321-340, 1991. 